\title{
Differences in the decomposition of green and senescent leaves in streams of Reserva Florestal Adolpho Ducke (Amazonas, Brazil)
}

\author{
Bianca Maíra de Paiva Ottoni-Boldrini
}

Coordenação de Biodiversidade, Instituto Nacional de Pesquisas da Amazônia (INPA), Av. André Araújo, 2936, Petrópolis, CEP 69067-375, Manaus, AM, Brasil. E-mail: biancaottoni@gmail.com

Recebido em: 21 de novembro de 2017. Aceito em: 08 de janeiro de 2018. Publicado PDF em: 18 de janeiro de 2018

\begin{abstract}
Differences in the decomposition of green and senescent leaves in streams of Reserva Florestal Adolpho Ducke (Amazonas, Brazil). Leaves are considered the main energetic resource supply among all the allochthonous organic material available for the small shaded streams. However, their processing is limited by the physical and chemical characteristics of the leaves. Therefore, this research aimed to: i) evaluate the difference in decomposition coefficients between green and senescent leaves; ii) compare richness and density of aquatic invertebrates colonizing decomposing green and senescent leaves. Between November 2012 and January 2013, 12 leaf packages (6 senescent and 6 green) of 14 plant species were installed in 3 streams of the Reserva Florestal Adolpho Ducke (Manaus/AM - Brazil). After 15, 30 and 60 days the submerged packages were removed. The collected material was taken to the laboratory for analyzes of: aquatic invertebrates and leaves' mass remnants. Paired t-test was performed to verify if the decomposition coefficients $(\mathrm{k})$ differed. ANCOVAs were performed to compare: the remaining mass (\%), richness and density of aquatic invertebrates between leaf type over time. The green leaves presented higher leaf decomposition rates than in senescent ones. The leaf type influenced the average invertebrates densities. Therefore, green leaves were more susceptible to the colonization of aquatic invertebrates associated with the leaf decomposition process in small Amazonian streams.
\end{abstract}

KEY WORDS: aquatic invertebrates, community structure, organic substrates, igarapés, tropical region.

\section{RESUMO}

Diferenças na decomposição de folhas verdes e senescentes em riachos da Reserva Florestal Adolpho Ducke (Amazonas, Brasil). As folhas são consideradas a principal fonte de recurso energético entre toda a matéria orgânica alóctone disponibilizada para os pequenos riachos sombreados. Porém, seu processamento é limitado por características físicas e químicas das folhas. Assim, esta pesquisa objetivou: i) avaliar as diferenças nos coeficientes de decomposição entre folhas verdes e senescentes; ii) comparar a riqueza e a densidade de invertebrados aquáticos que colonizam folhas verdes e senescentes em decomposição. Entre novembro de 2012 a janeiro de 2013, foram instalados 12 bolsas de folhas (6 senescentes e 6 verdes) de 14 espécies vegetais em 3 riachos da Reserva Florestal Adolpho Ducke (Manaus/AM - Brasil). Após 15, 30 e 60 dias houve a retirada das bolsas submersas. O material coletado foi levado ao laboratório para as análises de: invertebrados aquáticos e massa remanescentes de folhas. Teste-t pareado foi realizado para verificar se havia diferenças entre os coeficientes de decomposição (k). ANCOVAs foram realizadas para comparar: a massa remanescente (\%), riqueza e densidade de invertebrados aquáticos entre os tipos de folha ao longo do tempo. As folhas verdes apresentaram maiores taxas de decomposição foliar do que em senescentes. O tipo da folha influenciou as densidades médias de invertebrados. Portanto, folhas verdes foram mais susceptíveis a colonização de invertebrados aquáticos associados ao processo de decomposição foliar em riachos amazônicos.

PALAVRAS CHAVE: invertebrados aquáticos, estrutura de comunidade, substratos orgânicos, igarapés, região tropical 


\section{INTRODUCTION}

Leaves are considered the main energetic resource supply among all the allochthonous organic material available for the small shaded streams (França et al. 2009). However, the processing of this leaf material can be limited by the physical and chemical characteristics of the leaves that enter the streams (Rincón and Santelloco 2009; Bruder et al. 2014). For instance, leaves with high structural compounds concentrations (lignin and cellulose) may remain in the aquatic system for longer time (Moretti et al. 2007a, b), since these characteristics hinder the processing by the aquatic decomposing community (Ardón and Pringle 2008; Moretti et al. 2009).

The processing of leaf material involves the participation of two groups of organisms: the decomposers (bacteria and fungi) and the detritivores (animals that consume dead matter) (Townsend et al. 2006; Graça et al. 2001a,b; 2015). Bacteria and fungi are responsible for conditioning of plant material incorporated into the aquatic system (Gonçalves et al. 2006a, b; Alvim et al. 2015). Conditioning is the stage of leaf decomposition process in which microorganisms act on dead organic matter, making it more palatable to the detritivore community, especially aquatic invertebrates (Graça 2001; Gonçalves et al. 2014).

Aquatic invertebrates, especially the shredders, are responsible for transforming coarse particulate organic matter into fine particulate organic matter (Abelho 2001; Graça et al. 2015), acting directly on the leaf decomposition process (Webster and Benfield 1986; Gessner et al. 1999). The attractiveness of foliar debris to aquatic invertebrates has been associated with its chemical and physical composition, level of decomposition and microbial conditioning of the leaves (Abelho 2001; Graça et al. 2001a; Gonçalves et al. 2014; Alvim et al. 2015; Graça et al. 2015). In addition, the exposure time of the leaves can also be considered an important factor to determine the taxonomic composition of aquatic invertebrates involved in their decomposition (Ligeiro et al. 2010).

Most leaf decomposition studies are based on experiments using senescent leaves to represent the natural processes of leaf decomposition (see Gonçalves et al. 2014). The process of senescence consists of a series of biochemical event which results in the breakdown of biochemical compounds, culminating in the death of parts of the plant, such as leaves or the plant itself (Diaz et al. 2008; Hollmann et al. 2014; Jyothsna and Murthy 2016; Clément et al. 2017). Leaf senescence allows the translocation of nutrients such as Nitrogen (Diaz et al. 2008; Hollmann et al. 2014) from the senescent organs to other, growing plant organs, such as seeds (Clément et al. 2017). Therefore, senescence is considered the final stage of development for leaves. According to Peoples and Dalling (1988), up to $70 \%$ of the leaf nitrogen can be translocated from senescent organs to other parts of the plant. Thus, senescent leaves are considered less nutritious than green leaves (Kochi and Yanai 2006).

Some research on foliar decomposition has been developed with green leaves (Landeiro et al. 2008; Ferreira et al. 2012; Martins et al. 2015; Gonçalves et al. 2017), sometimes with the justification that green leaves represent an important energy source (Lopes et al. 2015), or due to the unfeasibility of collecting senescent leaves in some ecosystems. Thus, the use of green leaves almost always implies greater nutritional availability (Bastian et al. 2007) that allows for greater attractiveness to organisms associated with their decomposition, and, therefore, it assumes that their rates of decomposition are greater than with senescent leaves.

Therefore, this research aimed to: i. evaluate the difference in decomposition coefficients between green and senescent leaves; ii. compare richness and density of aquatic invertebrates colonizing decomposing green and senescent leaves.

\section{MATERIAL AND METHODS}

\section{Study area}

Sampling was conducted between November 2012 and January 2013 in three first- or second -order streams (Strahler 1952) at Reserva Florestal Adolpho Ducke (RFAD) (Figure 1). RFAD is a 10,000 ha $(10 \mathrm{~km} \times 10 \mathrm{~km})$ tropical forest environmental protection area located North of the city of Manaus, state of Amazonas, Brazil $\left(02^{\circ} 55^{\prime}-03^{\circ} 01^{\prime} \mathrm{S}\right.$; 59 53' $59^{\circ} 59^{\prime} \mathrm{W}$ ). This area is characterized by the humid tropical climate with two well-defined seasons (Köppen climate classification): a dry 


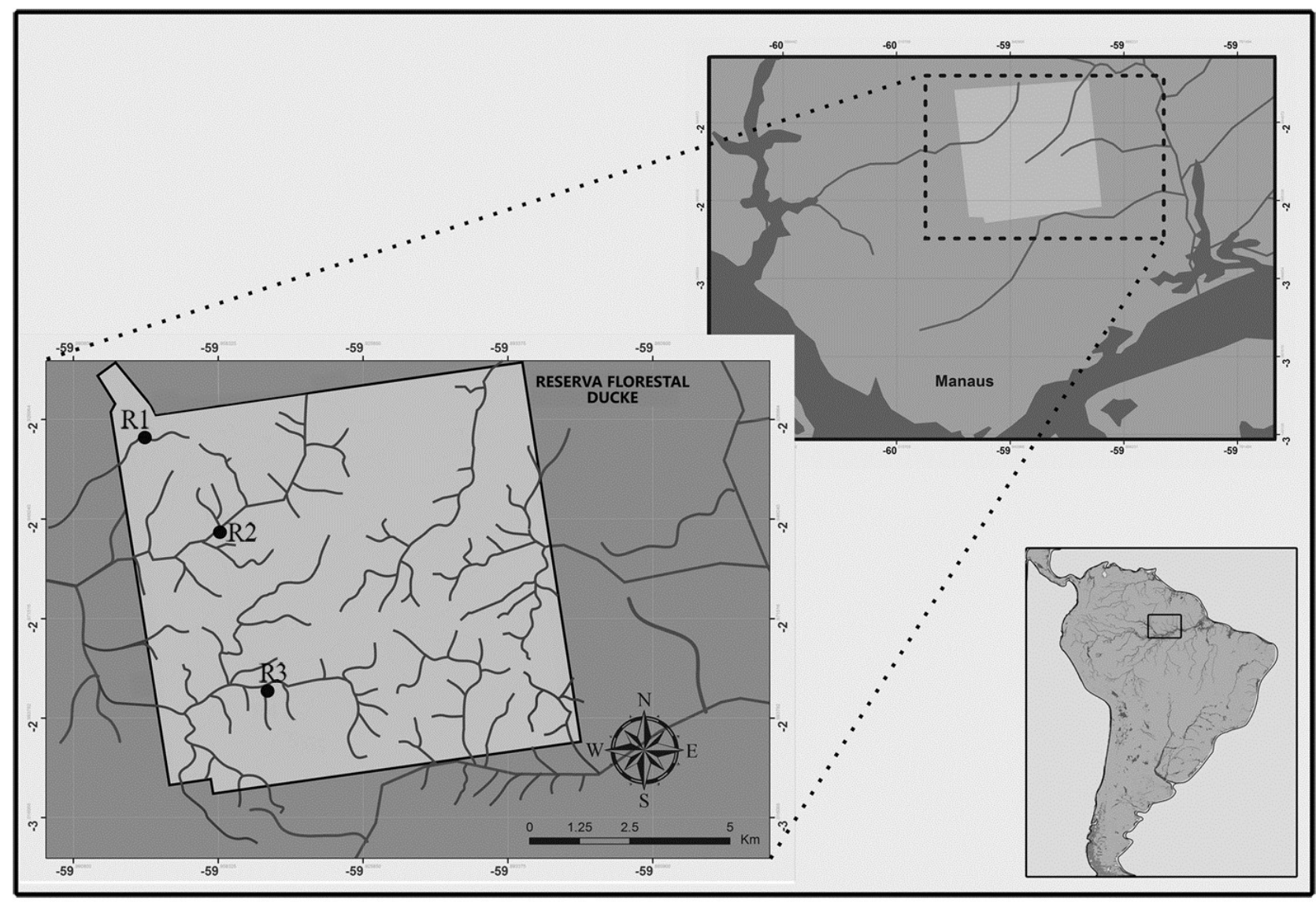

Figure 1. Localization of the three selected streams to carry out a leaf decomposition experiment located at Reserva Florestal Adolpho Ducke, Manaus (AM). Sampling was conducted between November 2012 and January 2013.

one, from June to November, and a wet one, from December to May. The annual average temperature is $26.7^{\circ} \mathrm{C}$ and the monthly average relative humidity is above $80 \%$ (Marques-Filho and Dallarosa 2000).

The studied streams present a predominantly sandy bed associated with accumulation of leaf litter or other plant material (trunks, branches and fruits) (Rezende 2007; Espírito-Santo et al. 2009); acidic $\mathrm{pH}$ between $4.19-4.50$ (average $4.36 \pm 0.11) ; \quad$ low average electrical conductivity $\left(11.18 \pm 2.97 \mu \mathrm{S} \mathrm{cm}^{-1}\right)$; average water temperature at approximately $25.09 \pm$ $0.37^{\circ} \mathrm{C}$ and water dissolved oxygen between $3.86-7.39 \mathrm{mg} \mathrm{l}^{-1}$ (average $4.98 \pm 1.09 \mathrm{mg} \mathrm{l}^{-1}$ ). Average stream width was $68 \pm 0.22 \mathrm{~cm}$, average depth was $7 \pm 0.03 \mathrm{~cm}$ and average speed, $0.16 \pm 0.07 \mathrm{~m} \mathrm{~s}^{-1}$.

\section{Experimental procedure}

Fourteen plant species were selected for this study: Croton lanjouwensis Jabl. (Euphorbiaceae), Hevea brasiliensis Müll. Arg.
(Euphorbiaceae), Dipteryx odorata (Aubl.) Willd. (Fabaceae), Eperua glabriflora (Ducke) R. S. Cowan (Fabaceae), Ficus sp. (Moraceae), Helicostylis tomentosa (Poepp. \& Endl.) Rusby (Moraceae), Carapa guianensis Aubl. (Meliaceae), Cecropia hololeuca Miq. (Cecropiaceae), Clusia sp. (Clusiaceae), Davilla rugosa Poir. (Dilleniaceae), Eugenia stipitata McVaugh (Myrtaceae), Lecythis pisonis Cambess (Lecythidaceae), Licania sp. (Chrysobalanaceae) and Ocotea nigrescens Vicent. (Lauraceae). Species were selected based on their occurrence among riparian vegetation in the studied streams and availability of their leaves.

Both senescent and green leaves (removed before natural abscission) were collected and taken to laboratory, where leaves were further selected, discarding those that presented foliar tissue damage or established microorganism colonies.

Leaves were then stored in hollow plastic containers (standard, $60 \mathrm{x} 40 \mathrm{~cm}$ ) to dry in controlled conditions $\left(\sim 72 \mathrm{~h}, 18^{\circ} \mathrm{C}\right)$.

A total of 504 leaf samples were used in this 
study, with 18 litter bags for each plant species and for each leaf state (green leaf or senescent leaf). Litter bags were made of plastic mesh measuring $10 \times 20 \mathrm{~cm}$, with a $1 \mathrm{~cm}^{2}$ opening between knots, containing approximately $2.13 \mathrm{~g}$ $( \pm 0.33 \mathrm{~g})$ of leaf litter.

All litter bags were submerged on the same date and secured by nylon cords attached by rods to the bed of the streams, maintaining a $10 \mathrm{~cm}$ distance between bags. Six packets of leaves of each plant species and each leaf state (senescent and green) were installed in each stream.

\section{Removal and processing of leaf litter bags}

After 15, 30 and 60 days of incubation, 4 litter bags were collected from each stream for each plant species, being 2 litter bags of senescent leaves and 2 of green leaves. The removed bags were immediately moved to individual plastic bags and transported in iceboxes to the Laboratório de Citotaxonomia e Insetos Aquáticos at Instituto Nacional de Pesquisas da Amazônia.

The leaves from each bag were carefully washed with distilled water in the laboratory over a sieve with a mesh aperture of $120 \mu \mathrm{m}$. A set of five leaf discs with a diameter of $1.2 \mathrm{~cm}$ was taken from each bag to estimate the ashfree dry mass (AFDM) (Graça et al. 2005). However, it was not possible to perform this procedure for all litter bags, because due to the advanced state of leaf decomposition there was not enough plant material remaining in some bags to perform the analyses.

\section{Leaf decomposition}

The percentage of remaining mass was estimated from the starting weight and final weight of the remaining material. The decomposition coefficient $(\mathrm{k})$ of the litter bags was obtained through a negative exponential model of the litter bag weight percentage over time $\left(\mathrm{W}_{\mathrm{t}}=\mathrm{W}_{0} \cdot \mathrm{e}^{-\mathrm{kt}}\right.$, where $\mathrm{W}_{\mathrm{t}}=$ final weight; $\mathrm{W}_{0}$ $=$ starting weight $-\mathrm{k}=$ decay rate and $\mathrm{t}=$ time) . Subsequently, the decomposition coefficients obtained were used to establish a regional classification for decomposition velocities.

AFDM estimates for each species were obtained from a set of leaf discs dried in a bacteriological stove $\left(50^{\circ} \mathrm{C}\right.$ for $\left.72 \mathrm{~h}\right)$, weighted with a precision analytical balance $(0.0001 \mathrm{~g})$ and calcined in a muffle oven $\left(500^{\circ} \mathrm{C}\right.$ for $\left.4 \mathrm{~h}\right)$.
After calcination, the remaining material was reweighed in a precision analytical balance and the AFDM values were extrapolated for the remaining litter mass (see Gonçalves et al. 2014).

\section{Aquatic invertebrates}

All aquatic invertebrates retained in the sieve after the leaves were washed were separated into plastic vials with ethyl alcohol at $80 \%$ and properly labeled. Subsequently, aquatic invertebrates were screened, quantified and identified at family level using stereoscopic microscopes and taxonomic keys by Pes et al. (2005); Pereira et al. (2007); Hamada and Ferreira-Keppler (2012) and Hamada et al. (2014). Examined specimens are deposited in the Invertebrate Collection of the Instituto Nacional de Pesquisas da Amazônia (INPA), Manaus, Amazonas, Brazil.

\section{Data analysis}

A paired t-test was performed to test whether the coefficients of decomposition $(\mathrm{k})$ presented significant differences between the studied leaf states (senescent vs. green). To compare the remaining mass (\%) between senescent and green leaves, time and the interaction between these two factors, Covariance analyses (ANCOVA) were performed considering time as covariate.

Covariance analyses (ANCOVA) were also used to compare biotic variables (richness and density) of aquatic invertebrates between leaf states over time (covariate). The interaction between the predictive variables (leaf state vs. incubation time) relative to response variables. Data were log-transformed for analysis when necessary $\left(\log _{(\mathrm{x}+1)}\right)$ (Zar 1996).

Statistical analyses consider the sample mean by type of detritus and by incubation time for each plant species. All analyses considered a $\mathrm{p}=0.05$ significance level and were performed using $\mathrm{R}$ software ( $\mathrm{R}$ Core Team 2013).

\section{RESULTS}

\section{Remaining mass and leaf decomposition coefficient}

The values of the decomposition coefficient (k) of the senescent leaves were significantly 
lower than the values found for the green leaves (paired T test: $\mathrm{t}=-4.2107$; $\mathrm{DF}=13 ; \mathrm{p}=$ 0.001) (Table 1). Thus, approximately 78 days of incubation would be necessary for the senescent leaves decay to reach $50 \%$ of mass decomposition, while for green leaves the 60 days of incubation were sufficient for this to occur. At 60 days of incubation, the remaining dry weight percentage ranged from 43.7 $79.4 \%$ for senescent leaves and $15.5-72.7 \%$ for green leaves, with mean values of $62.5 \%$ and $42.9 \%$, respectively (Figure 2). The percentage of remaining dry weight of leaf litter was significantly different for senescent and green leaves (ANCOVA: $\mathrm{F}=31.66$; $\mathrm{DF}=$

Table 1. Estimated decomposition coefficients for plant species used in the leaf decomposition experiment in three streams of the Reserva Florestal Adolpho Ducke, Manaus (AM).

\begin{tabular}{lcc}
\hline \multicolumn{1}{c}{ Leaf species } & \multicolumn{2}{c}{ Leaf state } \\
& $\begin{array}{c}\text { Senescent } \\
\text { (k day }^{-1} \text { ) }\end{array}$ & $\begin{array}{c}\text { Green } \\
\text { (k day }^{-1} \text { ) }\end{array}$ \\
\hline Clusia sp. & 0.005 & 0.009 \\
Eugenia stipitata & 0.010 & 0.013 \\
Carapa guianensis & 0.008 & 0.018 \\
Dipteryx odorata & 0.009 & 0.022 \\
Hevea brasiliensis & 0.014 & 0.024 \\
Ficus sp. & 0.010 & 0.020 \\
Cecropia hololeuca & 0.007 & 0.021 \\
Helicostylis tomentosa & 0.006 & 0.032 \\
Croton lanjouwensis & 0.009 & 0.008 \\
Ocotea nigrescens & 0.013 & 0.016 \\
Eperua glabriflora & 0.004 & 0.005 \\
Licania sp. & 0.014 & 0.016 \\
Davilla rugosa & 0.009 & 0.015 \\
Lecythis pisonis & 0.006 & 0.015 \\
Mean and standard & $0.009 \pm$ & $0.017 \pm$ \\
errors & 0.003 & 0.007 \\
\hline
\end{tabular}

$1, p<0.05)$ and for different incubation times (ANCOVA: $\mathrm{F}=27.22 ; \mathrm{DF}=2, \mathrm{p}<0.05$ ). However, no significant difference was found for the interaction of leaf state and time (ANCOVA: $\mathrm{F}=1.21 ; \mathrm{DF}=2 ; \mathrm{p}=0.30$ ) (Table 2).

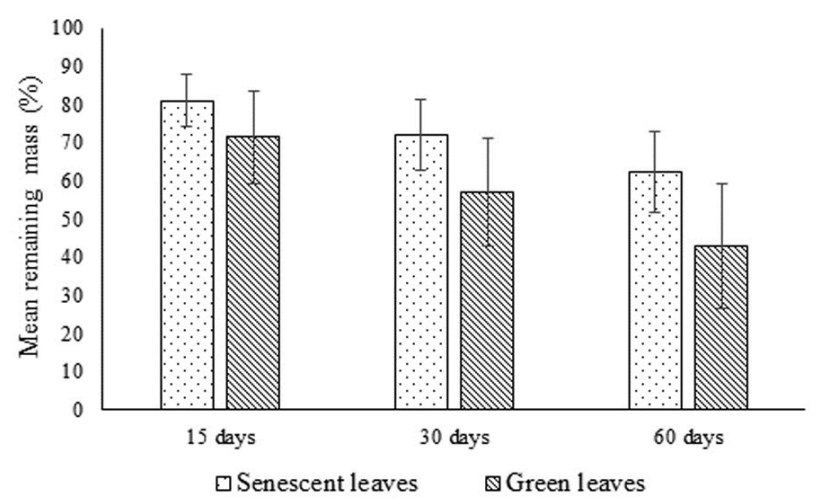

Figure 2. Mean percentage (columns) and standard errors (vertical bars) of the remaining mass senescent and green - throughout the days of immersion in an experiment carried out in three streams of the Reserva Floresta Adolpho Ducke, Manaus (AM). Sampling was conducted between November 2012 and January 2013.

\section{Aquatic invertebrates community}

A total of 18,617 aquatic invertebrate individuals were collected, distributed in 45 taxa, associated to leaf decomposition. Average taxon richness did not differ significantly between the types of debris studied (ANCOVA: $\mathrm{F}=0.05 ; \mathrm{DF}=1 ; \mathrm{p}=0.82$ ). However, there were significant differences relative to incubation time (ANCOVA: $\mathrm{F}=$ 72.27; $\mathrm{DF}=2 ; \mathrm{p}<0.05$ ). Average densities exhibited a constant increase over decomposition time, for both state of leaves. These values presented significant differences between types of leaf (ANCOVA: $\mathrm{F}=491.67$; $\mathrm{DF}=1 ; \mathrm{p}<0.05)$ and over sampling time (ANCOVA: $\mathrm{F}=136.71 ; \mathrm{DF}=2 ; \mathrm{p}<0.05$ ) (Table 2).

For all sampling events, green leaves presented higher average mean densities (Figure 3). At 15 days of incubation, green leaves presented $48.1 \pm 21.7$ ind. $\mathrm{g}^{-1}$ AFDM, reaching up to $104.6 \pm 80.5$ ind. $^{-1}$ AFDM at 60 days of incubation. For senescent leaves, these values were $18.2 \pm 9.8$ ind. $\mathrm{g}^{-1}$ AFDM and $45.6 \pm 21.6$ ind. $\mathrm{g}^{-1}$ AFDM, respectively (Figure 3).The composition of the community was similar among the leaf state studied. For example, in both cases the predominant taxa were Chironomidae (Diptera, Insecta), Leptohyphidae (Ephemeroptera, Insecta) and Hydroptilidae (Trichoptera, Insecta) (Figure 4 and 5). 


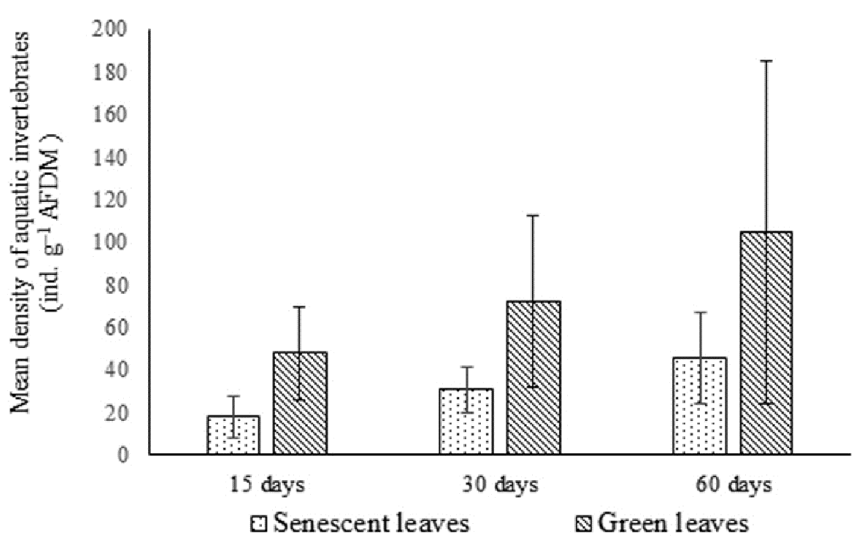

Figure 3. Mean density of aquatic invertebrates (columns) and standard errors (vertical bars) collected in the leaves analyzed throughout the days of immersion in an experiment carried out in three streams of the Reserva Floresta Adolpho Ducke, Manaus (AM). Sampling was conducted between November 2012 and January 2013.

\section{DISCUSSION}

\section{Remaining mass and leaf decomposition coefficient}

Green leaves presented higher decomposition rates than senescent leaves. Both leaf state presented average decomposition coefficients classified as "intermediate" according to the classification proposed by Gonçalves et al. (2014). However, the $\mathrm{k}$ value for green leaves was approximately twice as high as the value for senescent leaves, so that while green leaves lost over $50 \%$ of biomass in 60 days of debris incubation, senescent leaves would require more time. This indicates that changes in the composition of riparian vegetation, which will affect the quality of the leaf litter supplied to the streams, can impact the leaf decomposition process in

Table 2. Analysis of Covariance (ANCOVA) used to evaluate if the percentage of remaining mass and the aquatic invertebrates community (richness and density) showed differences between leaf state (green or senescent), incubation times $(15,30$ and 60 days) and the interaction of these two factors in a leaf decomposition experiment in three streams of the Reserva Florestal Adolpho Ducke, Manaus (AM).

\begin{tabular}{llccccc}
\hline Response variables & \multicolumn{1}{c}{$\begin{array}{c}\text { Predictive } \\
\text { variables }\end{array}$} & DF & $\begin{array}{c}\text { Sum of } \\
\text { squares }\end{array}$ & $\begin{array}{c}\text { Mean of } \\
\text { squares }\end{array}$ & F & p \\
\hline \% Remaining mass & Leaf state & 1 & 4524.5 & 4524.5 & 301.31 & $<\mathbf{0 . 0 5}$ \\
& Time & 2 & 7117.90 & 3559.00 & 237003.00 & $<\mathbf{0 . 0 5}$ \\
& Leaf state x Time & 2 & 445.40 & 222.70 & 14832.00 & 0.23 \\
& Residuals & 78 & 11712.90 & 150.20 & & \\
Aquatics & & & & & & \\
invertebrate \\
richness
\end{tabular}




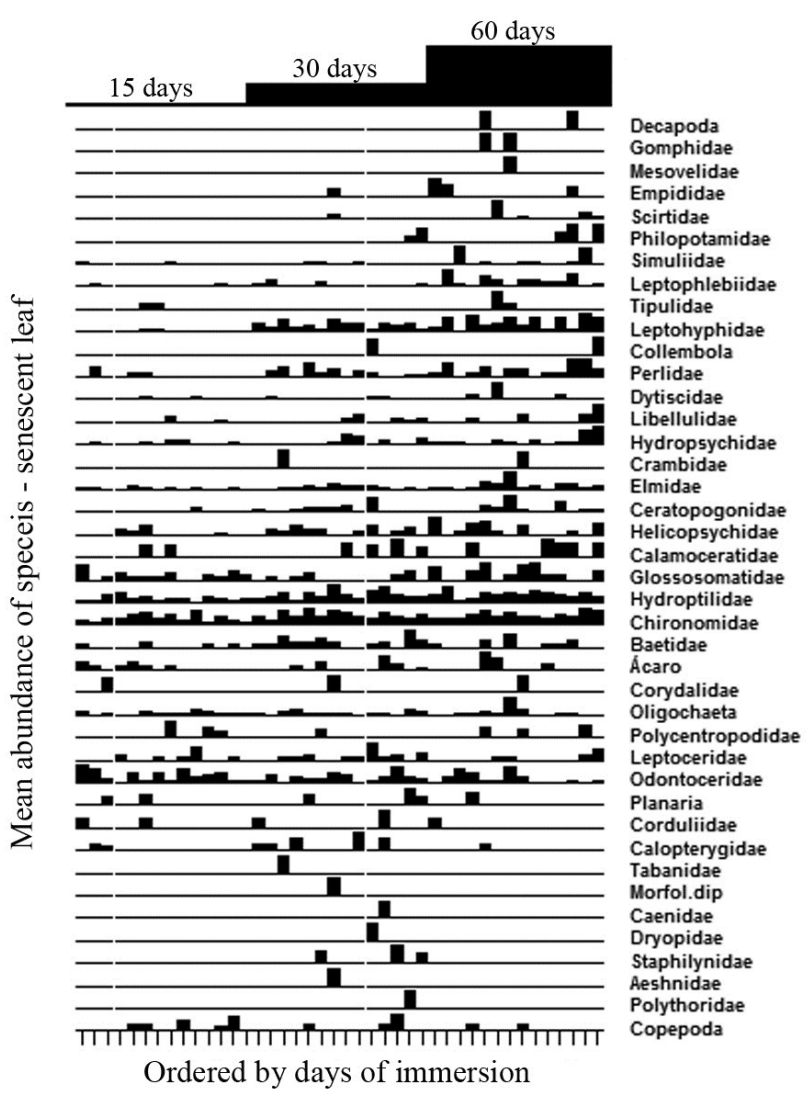

Figure 4. Mean abundance of aquatic invertebrates found in senescent leaves, ordered by the number of days of incubation in leaf decomposition experiment carried out in three streams of the Reserva Floresta Adolpho Ducke, Manaus (AM). Taxons were ordered on the y-axis. Sampling was conducted between November 2012 and January 2013.

these aquatic systems since the physical and chemical characteristics of the leaves are determinant of their decomposition rates (Biasi et al. 2016; Gonçalves et al. 2017).

\section{Aquatic invertebrates}

Aquatic invertebrates play an important role in the process of foliar decomposition, fragmenting and/or reducing coarse particulate matter into smaller parts (Graça 2001). In the present study, richness of invertebrate communities were similar for green and senescent leaves. Thus, although taxonomic richness is an important factor in community ecology, it may not be a good predictor for leaf decomposition studies, since taxonomic richness is not influenced by the nutritional quality of the leaf litter, due to the adaptation that different groups of invertebrates possess to explore different resources (König et al. 2014).

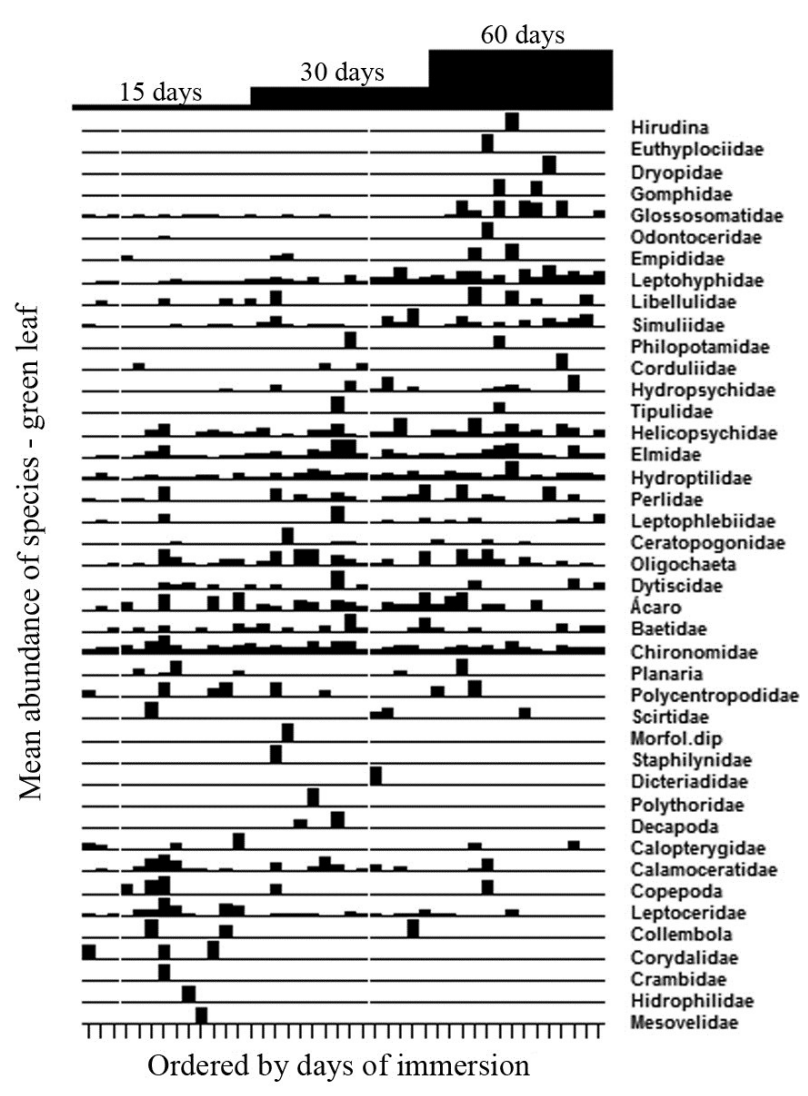

Figure 5. Mean abundance of aquatic invertebrates found in green leaves, ordered by the number of days of incubation in leaf decomposition experiment carried out in three streams of the Reserva Floresta Adolpho Ducke, Manaus (AM). Taxons were ordered on the y-axis. Sampling was conducted between November 2012 and January 2013.

The predominance of Chironomidae on green and senescent leaves agrees with other studies of leaf decomposition in streams in the Brazilian Amazon forest (e.g. Landeiro et al. 2008; Landeiro et al. 2010; Martins et al. 2015). These larvaes were found colonizing all the leaves studied in this study. These organisms are recognized for having generalist feeding habits (Roque and Trivinho-Strixino 2001; Trivinho-Strixino and Strixino 1999), and are important in the colonization of different state of foliar debris, regardless of their quality (Moretti et al. 2007a,b; Biasi et al. 2013). It is possible that such trophic behavior favored their plastic ability as colonizers, characterizing them as important biological agents in leaf decomposition. Moreover, they may act as essential agents in early stages of decomposition, when few organisms are able to act on submerged plant matter.

The data obtained showed that the mean 
densities of aquatic invertebrates were influenced by the leaf state and the time of removal from water. The patterns found for mean density of invertebrates were similar to those recorded in other studies, where the highest densities are found associated with latest sampling times (Kochi and Yanai 2006; Ligeiro et al. 2010; König et al. 2014). Higher invertebrate densities found in the longest incubation times may be a result of the aggregation of individuals over smaller amounts of leaves available (König et al. 2014).

In our study, in the last sampling event, much of the incubated debris had already been degraded both in green and senescent leaf samples. Thus, at that time, the lower availability of "leaf debris area" for colonization possibly led to the aggregation of individuals over available matter, thus increasing their densities. Furthermore, leaves in further stages of decomposition are likely a better substrate once they have undergone chemical and microbial conditioning, and, therefore, become more suitable for invertebrate colonization (Abelho 2001; Graça 2001).

\section{CONCLUSION}

In the beds of the small streams of the Amazon region, it is often possible to observe green leaves available, even though they are present in smaller quantities relative to senescent leaves. In our study, leaf decomposition rates were higher in green leaves than in senescent leaves. Aquatic invertebrate richness was not influenced by whether leaves were green or senescent. However, leaf type influenced the mean density of aquatic invertebrates. The higher density of organisms in the green leaves may be due to the chemical and physical characteristics that favor the colonization of these organisms. However, we suggest that larger studies are carried out to evaluate how the physical and chemical characteristics of the leaves and the fungal biomass are conduct throughout the process of leaf decomposition among the leaf types studied here.

\section{ACKNOWLEDGEMENTS}

Part of the funding for this research was provided by the Conselho Nacional de Desenvolvimento Científico e Tecnológico (CNPq proc. $\left.\mathrm{n}^{\mathrm{o}} 573976 / 2008-2\right)$ and by the Fundação de Amparo à Pesquisa do Estado do Amazonas (FAPEAM proc. $n^{\circ} 3159 / 2008$ ) for INCT-ADAPTA (Instituto Nacional de Pesquisa e Tecnologia). The author thank to CNPq (BIONORTE proc. $n^{0}$ 142014/2011-7 and proc. $\left.\mathrm{n}^{\mathrm{o}} 141494 / 2014-0\right)$ for the doctoral scholarship granted and the PRONEX-CNPq / FAPEAM project for the financial resource provided.

\section{REFERENCES}

Abelho, M. 2001. From litterfall to breakdown in streams: a review. The Scientific World, 1: 656-680.

Alvim, E.A.C.C.; Medeiros, A.O.; Rezende, R.S. \& Gonçalves, J.F.Jr. 2015. Leaf breakdown in a natural open tropical stream. Journal of Limnology (Online), 74: 248-260.

Ardón, M. \& Pringle, C.M. 2008. Do secondary compounds inhibit microbial-and insect-mediated leaf breakdown in a tropical rainforest stream, Costa Rica? Oecologia, 155: 311-323.

Bastian, M; Boyero, L.; Jackes, B.R. \& Pearson, R.G. 2007. Leaf litter diversity and shredder preferences in an Australian tropical rain-forest stream. Journal of Tropical Ecology, 23: 219-229.

Biasi, C.; Tonin, A.M.; Restello, R.M. \& Hepp, L.U. 2013. The colonisation of leaf litter by Chironomidae (Diptera): The influence of chemical quality and exposure duration in a subtropical stream. Limnologica - Ecology and Management of Inland Waters, 43: 427-433.

Biasi, C.; Cerezer, C. \& Santos, S. 2016. Biological colonization and leaf decomposition in a subtropical stream. Ecología Austral, 26: 189-199.

Bruder, A; Schindler, M.H.; Moretti, M.S. \& Gessner, M.O. 2014. Litter decomposition in a temperate and a tropical stream: the effects of species mixing litter quality and shredders. Freshwater Biology, 59: 438449.

Clément, G.; Moison, M.; Soulay, F.; Reisdorf-Cren, M. \& Masclaux-Daubresse, C. 2017. Metabolomics of laminae and midvein during leaf senescence and source-sink metabolite management in Brassica napus L. leaves. Journal of Experimental Botany, 10: 2513-2529.

Diaz, C.; Lemaître, T.; Christ, A.; Azzopardi, M.; Kato, Y.; Sato, F.; Morot-Gaudry, J.F.; Le Dily, F. \& Masclaux-Daubresse, C. 2008. Nitrogen recycling and remobilization are differentially controlled by leaf senescence and development stage in 
Arabidopsis under low nitrogen nutrition. Plant Physiology, 147: 1437-1449.

Espírito-Santo, H.M.V.; Magnusson, W.E.; Zuanon, J.; Mendonça, F.P. \& Landeiro, V.L. 2009. Seasonal variation in the composition of fish assemblages in small Amazonian forest streams: evidence for predictable changes. Freshwater Biology, 54: 536548.

Ferreira, S.J.F.; Miranda, S.A.F.; Marques filho, A.O. \& Silva, C.C. 2012. Efeito da pressão antrópica sobre igarapés na Reserva Florestal Adolpho Ducke, área de floresta na Amazônia Central. Acta Amazônica, 42: 533-540.

França, J.S.; Gregório, R.S.; D'Arc, J.P.; Goncalves, J.F.Jr.; Ferreira, F.A. \& Callisto, M. 2009. Composition and dynamics of allochthonous organic matter inputs and benthic stock in a Brazilian stream. Marine and Freshwater Research, 60: 990-998.

Gonçalves, J.F.Jr.; França, J.S.; Medeiros, A.O.; Rosa, C.A. \& Callisto, M. 2006a. Leaf Breakdown in a Tropical Stream. International Review of Hydrobiology, 91: 164-177.

Gonçalves, J.F.Jr.; Graça, M.A. \& Callisto, M. 2006b. Leaf-litter breakdown in 3 streams in temperate, Mediterranean, and tropical Cerrado climates. Journal of the North American Benthological Society, 25: 344-355.

Gonçalves, J.F.J.; Martins, R.T.; Ottoni, B.M.P. \& Couceiro, S.R.M. 2014. Uma visão sobre a decomposição foliar em sistemas aquáticos brasileiros. In: Hamada, N.; Nessimian, J.L. \& Querino, R.B. (Ed.). Insetos Aquáticos na Amazônia Brasileira: taxonomia, biologia e ecologia. Instituto Nacional de Pesquisas da Amazônia, Manaus, Amazonas, p.89-116.

Gonçalves, J.F.J, Couceiro, S.R.M., Rezende, R.; Martins, R.M.; Ottoni-Boldrini, B. M. P.; Campos, C.M.; Silva, J.O. \& Hamada, N. 2017. Factors controlling leaf litter breakdown in Amazonian streams. Hydrobiologia, 792: 195-207.

Graça, M.A.S. 2001. The role of invertebrates on leaf litter decomposition in streams - a review. International Revue Hydrobiologie, 86: 383-393.

Graça, M.A.S.; Cressa, C.; Gessner, M.O.; Feio, M.J.; Callies, K.A.E. \& Barrios, C. 2001a. Food quality, feeding preferences, survival and growth of shredders from tem- perate and tropical streams. Freshwater Biology, 46: 947-957.

Graça, M.A.S.; Ferreira, R.C.F. \& Coimbra, C.N. 2001 b. Litter processing along a stream gradient: the role of invertebrates and decomposers. Journal of the North American Benthological Society, 20: 408-420.

Graça, M.A.S.; Barlocher, F. \& Gessner, M.O. 2005. Methods to Study Litter decomposition. Springer, Netherlands, 319p.
Graça, M.A.S.; Ferreira, V.; Canhoto, C.; Encalada, A.C.; Guerrero-Bolaño, F.; Wantzen, K.M. \& Boyero, L. 2015. A conceptual model of litter breakdown in low order streams. International Review of Hydrobiology, 100: 1-12.

Hamada, N. \& Ferreira-Keppler, R.L. 2012. Guia Ilustrado de insetos aquáticos e semiaquáticos da Reserva Florestal Ducke. v.1. Universidade Federal do Amazonas, Manaus, Amazonas, 198p.

Hamada, N.; Nessimian, J.L. \& Querino, R.B. 2014. Insetos aquáticos na Amazônia brasileira: taxonomia, biologia e ecologia. Instituto Nacional de Pesquisas da Amazônia, Manaus, Amazonas, 724p.

Hollmann, J.; Gregersen, P.L. \& Krupinska, K. 2014. Identification of predominant genes involved in regulation and execution of senescence-associated nitrogen remobilization in flag leaves of field grown barley. Journal of Experimental Botany, 65 (14): 3963-3973.

Jyothsna, P. \& Murthy, S.D.S. 2016. A review on effect of senescence in plants and role of Phytohormones in delaying senescence. International Journal of Plant, Animal and Environmental Sciences, 6: 152-161.

Kochi, K. \& Yanai, S. 2006. Shredder colonization and decomposition of green and senescent leaves during summer in a headwater stream in northern Japan. Ecological Research, 21: 544-550.

König, R.; Hepp, L.U. \& Santos, S. 2014. Colonisation of low- and high-quality detritus by benthicmacroinvertebrates during leaf breakdown in a subtropical stream. Limnologica, 45: 61-68.

Landeiro, V.L.; Hamada, N. \& Melo, A.S. 2008. Responses of aquatic invertebrate assemblages and leaf breakdown to macroconsumer exclusion in Amazonian "terra firme" streams. Fundamental and Applied Limnology/Archiv für Hydrobiologie, 172: 49-58.

Landeiro, V.L.; Hamada, N.; Godoy, B.S. \& Melo, A.S. 2010. Effects of litter patch area on macroinvertebrate assemblage structure and leaf breakdown in Central Amazonian streams. Hydrobiologia, 649: 355-363.

Ligeiro, R.; Moretti, M.S.; Gonçalves, J.F.Jr. \& Callisto, M. 2010. What is more important for invertebrate colonization in a stream with low-quality litter inputs: exposure time of leaf species? Hydrobiologia, 654:125-136.

Lopes, M. P.; Martins, R.T.; Silveira, L.S. \& Alves, R. G. 2015. The leaf breakdown of Picramnia sellowii (Picramniales: Picramniaceae) as index of anthropic disturbances in tropical streams. Brazilian Journal of Biology, 75: 846-853.

Marques-Filho, A.O. \& Dallarosa, R.G. 2000. Interceptação de radiação solar e distribuição espacial de área foliar em floresta de terra firme da 
Amazônia Central. Acta Amazonica, 30: 453-470. Martins, R.T.; Melo, A.S.; Gonçalves, J.F.Jr. \& Hamada, N. 2015. Leaf-litter breakdown in urban streams of Central Amazonia: direct and indirect effects of physical, chemical, and biological factors. Freshwater Science, 34: 716-726.

Moretti, M.S.; Gonçalves, J.F.JR.; Ligeiro, R. \& Callisto, M. 2007a. Invertebrates colonization on tree leaves in a neotropical stream (Brazil). International Review of Hydrobiology, 92: 199-210.

Moretti, M.S.; Gonçalves, J.F.JR. \& Callisto, M. 2007b. Leaf breakdown in two tropical streams: differences between single and mixed species packs. Limnologica, 37: 250-258.

Moretti, M.; Loyola, R.; Becker, B. \& Callisto, M. 2009. Leaf abundance and phenolic concentrations codetermine the selection of case-building materials by Phylloicus sp. (Trichoptera, Calamoceratidae). Hydrobiologia, 630: 199-206.

Peoples, M.B. \& Dalling, M.J. 1988. The interplay between proteolysis and amino acid metabolism during senescence and nitrogen reallocation. In: Noodén, L.D.; Leopold, A.C. (Ed). Senescence and Aging in Plants. San Diego: Academic Press, p. 181217.

Pereira, D.L.V.; Melo, A.L. \& Hamada, N. 2007. Chaves de identificação de adultos para famílias e gêneros de heterópteros aquáticos e semi aquáticos na Amazônia Central, Brasil. Neotropical Entomology, 36: 210-228.

Pes, A.M.O.; Hamada, N. \& Nessimian, J.L. 2005. Chaves de identificação de larvas para famílias e gêneros de Trichoptera (Insecta) da Amazônia Central, Brasil. Revista Brasileira de Entomologia, 49: 181-204.

R CORE TEAM, 2013. R: A language and environment for statistical computing. R Foundation for Statistical Computing (http://www.R-project.org). Acesso em: 20/06/2017.

Rezende, C.F. 2007. Estrutura da comunidade de macroinvertebrados associados ao folhiço submerso de remanso e correnteza em igarapés da Amazônia Central. Biota Neotropica, 7: 301-306.

Rincón, J. \& Santelloco, R. 2009. Aquatic fungi associated with decomposing Ficus sp. leaf litter in a neotropical stream. Journal of the North American Benthological Society, 28: 416-425.

Roque, F.O. \& Trivinho-Strixino, S. 2001. Benthic macroinvertebrates in mesohabitats of different spatial dimensions in a first order stream (São Carlos -SP). Acta Limnologica Brasiliensia, 13: 69-77.

Strahler, A.N. 1952. Hypsometric (area-altitude) analysis of erosional topography. Geological Society of American Bulletin, 63: 1117-1142.

Townsend, C.R.; Begon, M. \& Harper, J.P. 2006.
Fundamentos em Ecologia. 2nd ed. Artmed, Porto Alegre, 592p.

Trivinho-Strixino, S. \& Strixino, G. 1999. Insetos dípteros: quironomídeos. In: Ismael, D.; Valenti, W.C.; Matsumura-Tundisi, T.; Rocha, O. (Ed.). Biodiversidade do Estado de São Paulo: Invertebrados de água doce, FAPESP, São Paulo, p.141-148.

Zar, J.H. 1996. Biostatistical analysis. 3nd ed. Prentice Hall, Upper Saddle River, New Jersey, 662p. 